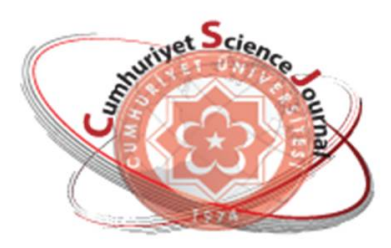

e-ISSN: $2587-246 X$

ISSN: 2587-2680

\section{Cumanoryet Science Journal}

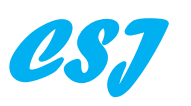

Cumhuriyet Sci. J., Vol.40-1(2019) 204-212

\title{
Effect of Ambient and Cryogenic Milling on the Microstructure and Properties of Tungsten Matrix Composites Fabricated by Activated Sintering
}

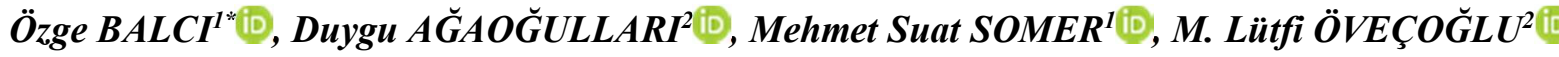 \\ ${ }^{1}$ Koç University, Department of Chemistry, İstanbul, TURKEY \\ ${ }^{2}$ İstanbul Technical University, Department of Metallurgical and Materials Engineering, Particulate Materials \\ Laboratories (PML), Istanbul, TURKEY
}

Received: 29.01.2018; Accepted: 25.12.2018

http://dx.doi.org/10.17776/csj.385724

\begin{abstract}
Tungsten matrix composites reinforced with $\mathrm{TiB}_{2}$ and $\mathrm{Y}_{2} \mathrm{O}_{3}$ particles were fabricated by milling under ambient/cryogenic conditions and $\mathrm{Ni}$ activated sintering. Powder blends constituting the $\mathrm{W}-1$ wt. \% Ni - 2 wt. $\% \mathrm{TiB}_{2}-1$ wt. $\% \mathrm{Y}_{2} \mathrm{O}_{3}$ composition were mechanically milled for $12 \mathrm{~h}$ under ambient condition or cryomilled for $10 \mathrm{~min}$ or sequentially milled under ambient and cryogenic conditions. Milling was carried out in a high-energy ball mill under ambient condition whereas cryogenic milling was conducted in externally circulated liquid nitrogen. Milled powders were compacted using a hydraulic press and the pellets were sintered at $1400^{\circ} \mathrm{C}$ for $1 \mathrm{~h}$ under $\mathrm{Ar} / \mathrm{H}_{2}$ gas flowing conditions. The effects of different milling types on the microstructural and mechanical properties of the sintered composites were investigated. After sintering, in addition to dominant $\mathrm{W}$ phase, small amounts of WB and NiW phases were detected in all sintered samples. The application of cryomilling after milling at ambient condition provided the disappearance of the clustered $\mathrm{TiB}_{2}$ and $\mathrm{Y}_{2} \mathrm{O}_{3}$ particles in the sintered sample: They were located at the grain boundaries of W1Ni matrix and homogeneously distributed through the microstructure. Sequentially milled and sintered composite had the highest relative density $(95.77 \%)$ and the highest microhardness (7.23 GPa) values among the samples. Nanoindentation tests showed that there was an improvement in the hardness and elastic modulus of $\mathrm{W}$ matrix phase, which yielded the values of 8.9 and $373.7 \mathrm{GPa}$, respectively.
\end{abstract}

Keywords: Tungsten matrix composites, Cryomilling, Activated sintering, $\mathrm{TiB}_{2}, \mathrm{Y}_{2} \mathrm{O}_{3}$.

\section{Normal ve Kriyojenik Şartlarda Öğütmenin Aktive Edilmiş Sinterleme Süreçleri ile Geliştirilen Tungsten Esaslı Kompozitlerin Mikroyapı ve Özellikleri Üzerindeki Etkisi}

Özet. Bu çalışmada, Ni ile aktive edilerek sinterlenen tungsten esaslı matrisin $\mathrm{TiB}_{2}$ ve $\mathrm{Y}_{2} \mathrm{O}_{3}$ partikülleri ile takviye edilmesiyle, tungsten esaslı kompozit malzeme üretimi gerçekleştirilmiştir. W - \% 1 ağ. Ni - \% 2 ağ. $\mathrm{TiB}_{2}-\% 1$ ağ. $\mathrm{Y}_{2} \mathrm{O}_{3}$ kompozisyonundan oluşan toz harmanları, normal koşullarda 12 sa mekanik olarak öğütülerek ya da $10 \mathrm{dk}$ kriyojenik ortamda öğütülerek ya da normal ve kriyojenik şartlarda ardışık olarak öğütülerek hazırlanmıştır. Normal şartlarda öğütme yüksek enerjili bir değirmende uygulanırken; kriyojenik şartlarda öğütme sıvı azot ile dışarıdan çevrelenen bir sistemde yapılmıştır. Öğütülmüş tozlar hidrolik pres kullanılarak preslenmiş ve pekiştirilen bünyeler $\mathrm{Ar} / \mathrm{H}_{2}$ gazaltı şartlarında $1400^{\circ} \mathrm{C}$ 'de 1 sa sinterlenmiştir. Farklı öğütme koşullarının sinterlenen kompozit malzemelerin mikroyapısı ve özellikleri üzerindeki etkisi incelenmiştir. Sinterlenme sonrasında, baskın W fazına ek olarak düşük mikarda WB ve NiW fazları oluşumu gözlemlenmiştir. Normal şartlarda öğütme sonrası uygulanan kriyojenik öğütme, sinter malzemelerin

\footnotetext{
* Corresponding author. Email address: obalci@ku.edu.tr

http://dergipark.gov.tr/csj C2016 Faculty of Science, Sivas Cumhuriyet University
} 
mikroyapısındaki $\mathrm{TiB}_{2}$ ve $\mathrm{Y}_{2} \mathrm{O}_{3}$ partiküllerin topaklanmasının yok olmasına neden olmuştur: Partiküllerin W1Ni matrisinin tane sınırlarında ve homojen olarak mikroyapıda dağılması sağlanmıştır. Ardışık olarak ögütülmüş ve sinterlenmiş kompozitler, numuneler arasında en yüksek rölatif yoğunluk $(\% 95,77)$ ve mikrosertlik değerlerini (7,23 GPa) sunmuştur. Nano-indentasyon testleri sayesinde, W matris fazının sertlik ve elastisite modül değerlerinin sırasıyla 8,9 ve 373,7 GPa değerlerine kadar iyileştirildiği kanıtlanmıştır.

Anahtar Kelimeler: Tungsten esaslı kompozitler, kriyojenik öğütme, aktive edilmiş sinterleme, $\mathrm{TiB}_{2}, \mathrm{Y}_{2} \mathrm{O}_{3}$.

\section{INTRODUCTION}

Tungsten (W) and its composites are candidate materials for important structural applications at high temperatures due to their excellent properties such as high melting point, high elastic modulus, high thermal shock resistance, low thermal expansion coefficient, good corrosion resistance and good high-temperature strength and stiffness [1-2]. However, the densification of $\mathrm{W}$ is very difficult due to its high melting point and low ductility [3-4]. In recent years, fully dense W composites have been fabricated at much lower temperatures by utilizing powder metallurgy and advanced sintering techniques or the addition of some transition elements or their compounds [4-5]. Activated sintering of $\mathrm{W}$ and $\mathrm{W}$ matrix composites with the small amounts of metallic additives (such as $\mathrm{Ni}, \mathrm{Co}, \mathrm{Fe}$, etc.) resulted in highly densified sintered bodies [6-7]. Furthermore, hightemperature materials such as borides, nitrides, carbides or oxides have been also added to tungsten to enhance the mechanical properties at elevated temperatures [4, 8-12].

Therefore, activated sintering of $\mathrm{W}$ and $\mathrm{W}$ matrix composites reinforced with different carbide, nitride and oxide phases have been attracted great attention in the current literature [5, 12-16]. Among the boride reinforcement particles, titanium diboride $\left(\mathrm{TiB}_{2}\right)$ is an important ultra-high temperature ceramic with excellent properties such as high melting point, high temperature strength and good chemical resistance [17]. There are several researches reporting the fabrication and characterization of tungsten matrix composites reinforced with $\mathrm{TiB}_{2}$ and/or $\mathrm{Y}_{2} \mathrm{O}_{3}$ particles [18-20]. Furthermore, Ni powders added into the $\mathrm{W}$ by mechanical alloying process enables a rapid solidstate incorporation of the sintering aid into the matrix with an enhanced activation as well as particle size reduction [21]. Generally, mechanical milling under ambient condition has been used as powder preparation technique of $\mathrm{W}$-based powders [14-16]. However, milling under different conditions and its effects on the microstructure and final properties of the $\mathrm{W}$ sintered bodies are not a considerably discussed topic [22]. The addition of transition metal diborides as well as oxide particles and milling of these powders under cryogenic conditions can be suggested as an alternative powder preparation technique for tungsten matrix composites [22-23].

The aim of the present study is to report the effects of milling under ambient and/or cryogenic conditions on the microstructural and mechanical properties of the $\mathrm{Ni}$ activated sintered tungsten matrix composites reinforced with $\mathrm{TiB}_{2}$ and $\mathrm{Y}_{2} \mathrm{O}_{3}$ particles.

\section{EXPERIMENTAL PROCEDURE}

\subsection{Fabrication of the composites}

Elemental tungsten (W, Eurotungstene ${ }^{\mathrm{TM}}, 99.9 \%$ purity, 4-7 $\mu \mathrm{m}$ particle size range) and nickel $(\mathrm{Ni}$, $\mathrm{ABCR}^{\mathrm{TM}}, 99.9 \%$ purity, 3-7 $\mu \mathrm{m}$ particle size range) powders were used as the matrix metal and as the activated sintering agent, respectively. Titanium diboride $\left(\mathrm{TiB}_{2}\right.$, Alfa Aesar ${ }^{\mathrm{TM}}, 99.5 \%$ purity, 40-44 $\mu \mathrm{m}$ particle size range) and yttrium oxide $\left(\mathrm{Y}_{2} \mathrm{O}_{3}\right.$, Alfa Aesar ${ }^{\mathrm{TM}}, 99.99 \%$ purity, 8-10 $\mu \mathrm{m}$ particle size range) powders were utilized as reinforcement and dispersoid materials, respectively. The content of $\mathrm{Ni}$ activated sintering aid was selected as 1 wt. \% of W matrix: Previous studies carried out in our laboratory facilities revealed that $1 \mathrm{wt} . \% \mathrm{Ni}$ is an adequate agent amount for the activated sintering of $\mathrm{W}[12,14]$. Thus, 1 wt. $\% \mathrm{Ni}$ added $\mathrm{W}$ powders were mechanically milled for $6 \mathrm{~h}$ and they are hereafter 
referred to as $\mathrm{W} 1 \mathrm{Ni}$ pre-alloy. In order to compensate for the size ranges of the reinforcement and dispersoid particles, $\mathrm{TiB}_{2}$ and $\mathrm{Y}_{2} \mathrm{O}_{3}$ powders were pre-milled separately for $6 \mathrm{~h}$. W1Ni pre-alloy, pre-milled $\mathrm{TiB}_{2}$ and pre-milled $\mathrm{Y}_{2} \mathrm{O}_{3}$ powders were blended to constitute the composition of W1Ni-2 wt. $\% \mathrm{TiB}_{2}-1$ wt. $\% \mathrm{Y}_{2} \mathrm{O}_{3}$ (referred to as-blended $\left.\mathrm{W} 1 \mathrm{Ni}-2 \mathrm{TiB}_{2}-1 \mathrm{Y}_{2} \mathrm{O}_{3}\right)$.

Mechanical milling under ambient condition was carried out in a Spex ${ }^{\mathrm{TM}}$ 8000D Mixer/Mill (at a rate of $1200 \mathrm{rpm}$ ) for $12 \mathrm{~h}$ using a tungsten carbidecobalt (WC-Co) vial (50 ml capacity) and WC-Co balls $(\phi 6.5 \mathrm{~mm})$ with a ball-to-powder weight ratio (BPR) of 7:1 (total powder amount: 7 g). Prealloying of W1Ni and pre-milling of $\mathrm{TiB}_{2}$ and $\mathrm{Y}_{2} \mathrm{O}_{3}$ were also conducted at the same conditions with those used in mechanical milling experiments. Cryomilling was conducted in a $\mathrm{Spex}^{\mathrm{TM}} 6870$ Freezer/Mill (at a rate of 900 collisions/min) for 10 min using a cylindrical polycarbonate vial and stainless steel rods. Before milling processes, the vials were evacuated and back-filled with $\mathrm{Ar}$ gas (Linde $^{\mathrm{TM}}, 99.999 \%$ purity) in a Plaslabs ${ }^{\mathrm{TM}}$ glove box. Vials were soaked into liquid nitrogen (Linde $^{\mathrm{TM}}$, refrigerated) without a direct powdernitrogen contact. After milling processes, powders were unloaded under Ar atmosphere. Hereafter, asblended $\mathrm{W} 1 \mathrm{Ni}-2 \mathrm{TiB}_{2}-1 \mathrm{Y}_{2} \mathrm{O}_{3}$ powders milled for 12 $\mathrm{h}$ under ambient condition is referred to as $\mathrm{S} 1$, cryomilled for $10 \mathrm{~min}$ in the presence of externally circulated liquid nitrogen around vial is referred to as $\mathrm{S} 2$ and sequentially milled for $12 \mathrm{~h}$ under ambient condition and cryomilled for $10 \mathrm{~min}$ is referred to as S3. All powders were compacted to obtain cylindrical specimen with a diameter of 6.5 $\mathrm{mm}$ : Uni-action hydraulic press was used under a uniaxial pressure of $400 \mathrm{MPa}$ (10 ton capacity MSE $^{\mathrm{TM}}$ MP-0710). The pressed samples were sintered at $1400{ }^{\circ} \mathrm{C}$ for $1 \mathrm{~h}$ in a high-temperature controlled atmosphere furnace (Linn ${ }^{\mathrm{TM}}$ HT-1800) under $\mathrm{Ar} / \mathrm{H}_{2}$ gas flowing conditions with a heating and cooling rate of $10^{\circ} \mathrm{C} / \mathrm{min}$.

\subsection{Characterization studies}

X-ray diffraction (XRD) investigations were carried out using a Bruker ${ }^{\mathrm{TM}}$ D8 Advanced Series powder diffractometer with $\mathrm{CuK}_{\alpha}(\lambda=1.5406 \AA)$ radiation incremented at a step size of $0.02^{\circ}$ at a rate of $2 \% \mathrm{~min}$. The International Center for Diffraction Data ${ }^{\circledR}$ (ICDD) powder diffraction files were utilized for the identification of crystalline phases. The average crystallite sizes and lattice strains of the $\mathrm{W}$ phase in the milled powders were determined using a Bruker ${ }^{\mathrm{TM}}$-AXS TOPAS V3.0 software based on the modified Scherrer's formula. The most intense XRD diffraction peaks with (110), (200) and (211) reflections were fitted according to the Lorentzian profile by applying fundamental parameters approach. Particle size measurements of the milled powders were conducted using a Microtrac ${ }^{\mathrm{TM}}$ Nano-flex particle size analyzer (PSA) equipped with a Bandelin Sonopuls ${ }^{\mathrm{TM}}$ ultrasonic homogenizer using distilled water as the aqueous media.

Densities of the sintered composites were determined by Archimedes method using ethanol and the result of each sample was reported as the arithmetic mean of five different measurements. Microstructures of the samples were examined using a Hitachi $^{\mathrm{TM}}$ TM-1000 scanning electron microscope (SEM) operated at $15 \mathrm{kV}$. A series of metallographic treatments including grinding and polishing were applied and the polished samples were coated by gold to provide electrical conductivity during SEM analysis. Vickers microhardness measurements of the sintered samples were conducted using a Shimadzu ${ }^{\mathrm{TM}} \mathrm{HMV}$ Microhardness Tester under a load of $100 \mathrm{~g}$ for 10 $\mathrm{s}$ and the result of each sample includes the arithmetic mean of twenty successive indentations with a standard deviation. Nano-indentation measurements were performed at a peak load of 50 $\mathrm{mN}$ using an Agilent G200 nano-indenter. Loaddisplacement curve of the sintered sample was obtained from the matrix and reinforcement/dispersoid phases with a holding time of $5 \mathrm{~s}$. In addition, the nanohardness and elastic modulus values obtained from nanoindentation tests were reported.

\section{RESULTS AND DISCUSSION}

Figure 1 illustrates the XRD patterns of the milled W1Ni-2 $\mathrm{TiB}_{2}-1 \mathrm{Y}_{2} \mathrm{O}_{3}$ powders using different milling types under ambient and/or cryogenic 
conditions (S1, S2 and S3). As shown in Figure 1, all milled powders contain only the $\mathrm{W}$ phase (ICDD Card No: 04-0806, Bravais lattice: bodycentered cubic, $a=b=c=0.316 \mathrm{~nm}$ ). No peaks belonging to the $\mathrm{Ni}, \mathrm{TiB}_{2}$ and $\mathrm{Y}_{2} \mathrm{O}_{3}$ phases were identified in the XRD patterns after milling under ambient and/or cryogenic conditions. The absence of these phases was probably due to their very small amounts in the total powders and/or peak broadening caused by the continuous deformation during milling. Furthermore, any diffraction peak belonging to a secondary phase was not detected after milling at different conditions, indicating that no reaction took place between $\mathrm{W}, \mathrm{Ni}, \mathrm{TiB}_{2}$ and $\mathrm{Y}_{2} \mathrm{O}_{3}$ particles. WC contamination was previously observed for the $\mathrm{W}$ composites mechanically alloyed for $24 \mathrm{~h}$ using a high energy ball mill (1200 $\mathrm{rpm}$ ) in a WC vial with WC balls with a BPR of 10:1 [20]. However, the XRD patterns in Figure 1 do not show the emergence of WC phase in the broad $\mathrm{W}$ peaks after milling at different conditions, most likely due to its very small content in the $\mathrm{W}$ matrix. Therefore, milling for $12 \mathrm{~h}$ is a sufficient milling time without any WC contamination in visible amount, considering the milling times in literature $[20,24]$.

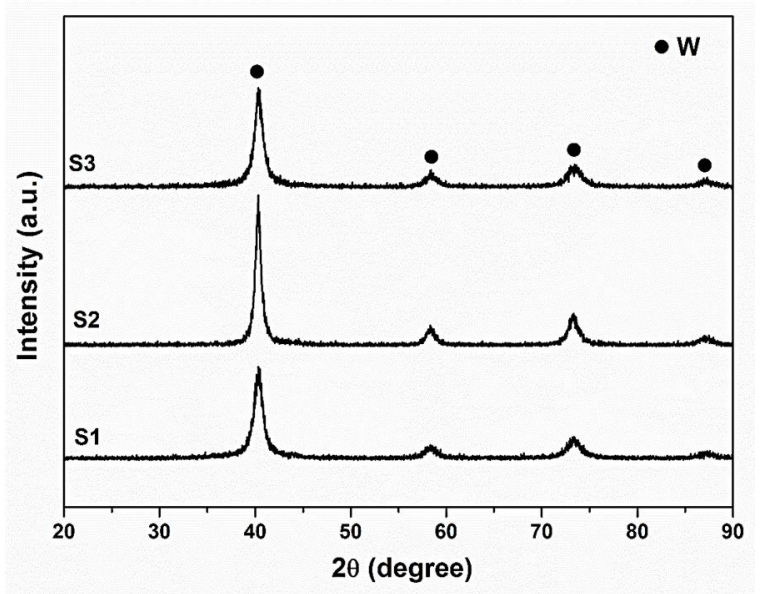

Figure 1. XRD patterns of the milled powders.

To reveal the effect of different milling types under ambient and/or cryogenic condition on the composite powders, the average crystallite sizes and lattice strains of the $\mathrm{W}$ phase in the milled powders (S1, S2 and S3) were determined (Table 1). The average crystallite size and lattice strain of the $\mathrm{W}$ phase in the S1 sample were found as 10.2 $\mathrm{nm}$ and $2.50 \%$. The small crystallite size is a result of continuous fracturing and welding mechanism triggered by the high impact energy released from the collisions of powders with vial and balls during milling under ambient condition. In the cryomilled powders (S2); however, the average crystallite size of the $\mathrm{W}$ phase is higher $(16.4 \mathrm{~nm})$ and the lattice strain is lower (1.54\%) than those of the S1 sample. This issue is also observable in the XRD peaks in Figure 1 supporting that higher broadening of the $\mathrm{W}$ peaks results in higher decrease in the average crystallite size and increase in the lattice strain. Furthermore, the average crystallite size $(9.3 \mathrm{~nm})$ and lattice strain $(2.77 \%)$ values of the $\mathrm{W}$ phase in the sequentially milled powders (S3) are similar to those of the S1 sample.

Table 1. Average crystallite sizes and lattice strains of the milled powders.

\begin{tabular}{ccc}
\hline $\begin{array}{c}\text { Sample } \\
\text { Name }\end{array}$ & $\begin{array}{c}\text { Crystallite Size } \\
\text { (nm) }\end{array}$ & $\begin{array}{c}\text { Lattice Strain } \\
\text { (\%) }\end{array}$ \\
\hline S1 & 10.2 & 2.50 \\
S2 & 16.4 & 1.54 \\
S3 & 9.3 & 2.77 \\
\hline
\end{tabular}

Figure 2(a) shows the average particle sizes of the milled powders. Considering the initial average particle sizes of the powders, it can be said that milling of the W1Ni-2 $\mathrm{TiB}_{2}-1 \mathrm{Y}_{2} \mathrm{O}_{3}$ powders under ambient condition for $12 \mathrm{~h}$ resulted in a significant decrease in the average particle size of the S1 powders $(282.3 \mathrm{~nm})$. SEM image of the milled S1 powders is given in Figure 2(b), showing the agglomeration of the powder particles during highenergy ball milling. The average particle size of S2 sample is lower $(270.8 \mathrm{~nm})$ than that of $\mathrm{S} 1$, indicating that cryomilling enables the prevention of agglomeration. The repeated fracturing and welding mechanism in the presence of an amount of temperature increase during high-energy ball milling could result in a higher average particle size value in the S1 sample than that of S2, even if longer milling time was used. On the other hand, cryomilling has the advantage of hindering rewelding mechanism thanks to the externally circulated liquid nitrogen. The combined process of milling under ambient and cryogenic conditions 
should be more beneficial for particle refinement and prevention of agglomeration. Thus, there is a remarkable decrease in the average particle size of S3 $(215.7 \mathrm{~nm})$, compared to that of S1 $(282.3 \mathrm{~nm})$. This means that subsequent 10 min of cryomilling provided breaking down of the agglomerated particles.

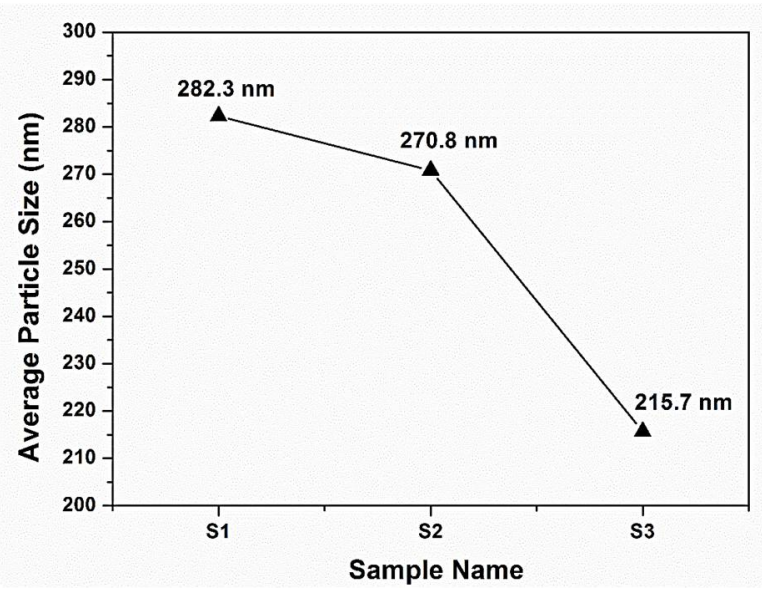

(a)

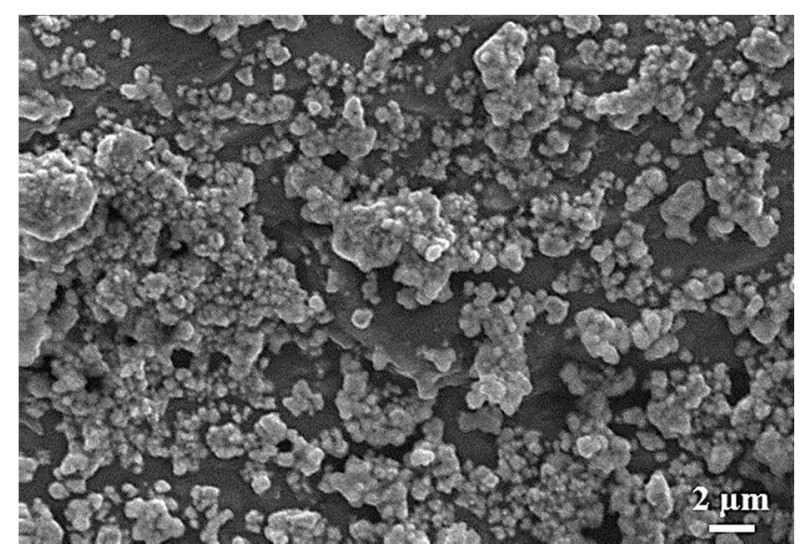

(b)

Figure 2. (a) Average particle sizes of the milled powders and (b) SEM image of the milled S1 powders.

Figure 3 shows the XRD patterns of the bulks samples sintered from the S1, S2 and S3 powders. High temperature during sintering resulted in an increase in the XRD peak intensities as compared with those of powders illustrated in Figure 1, that this indicated improved crystallinity (Figure 3). As seen from Figure 3, all sintered samples contain the peaks of WB and NiW phases in addition to the major $\mathrm{W}$ phase which was already present in the milled powders (Figure 1). Small amount of Ni (1 wt. \%) went into the $\mathrm{W}$ solid solution and caused the emergence of $\mathrm{Ni}(\mathrm{W})$ solid solution phase. Furthermore, no diffraction peaks of $\mathrm{TiB}_{2}$ and $\mathrm{Y}_{2} \mathrm{O}_{3}$ were observed after sintering, most likely due to their small amounts and broad peaks dominated by the intense peaks of the $\mathrm{W}$ phase. Similarly, the characteristic peaks of the boride, carbide and oxide phases have not been observed in the $\mathrm{W}$ matrix composites reported in literature $[12,16$, 22]. Additionally, the formation of WB compound is due to the diffusion of decomposed $\mathrm{TiB}_{2}$ into the W1Ni matrix. On the other hand, W or Ni based intermetallic compound (such as $\mathrm{W}_{5} \mathrm{Si}_{3}$, NiTi etc.) or WC contamination was not identified after sintering at $1400{ }^{\circ} \mathrm{C}$, as shown in Figure 3: These phases have been already reported for the sintered W matrix composites reinforced with carbide/boride and oxide particles [12, 19, 20]. The present result can be attributed to the proper amount of the reinforcement ( $2 \mathrm{wt} . \%$ in the total composition) which does not cause emergence or enhancement of the contamination and intermetallics.

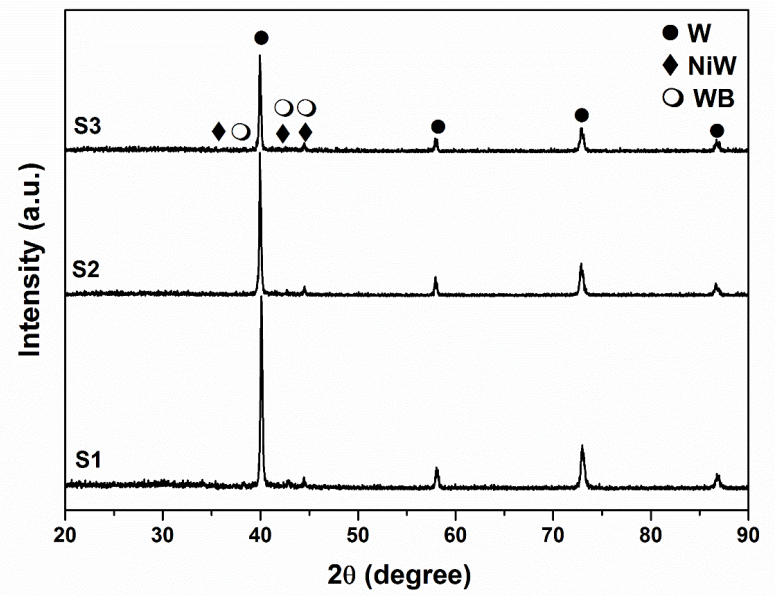

Figure 3. XRD patterns of the sintered samples.

Figure 4 shows the BSE/SEM images of the sintered samples taken from the polished surfaces. $\mathrm{TiB}_{2}$ and $\mathrm{Y}_{2} \mathrm{O}_{3}$ particles (dark contrast) which are located both at the grain boundaries and at the grain interiors of $\mathrm{W} 1 \mathrm{Ni}$ matrix (light contrast) are representatively signed in the SEM image of $\mathrm{S} 1$ sample. Some clustered areas of the $\mathrm{TiB}_{2}$ and $\mathrm{Y}_{2} \mathrm{O}_{3}$ particles are detected through the microstructures 
of both S1 and S2 samples. The pores are observable in the SEM image of S2 sample, indicating the insufficient sintering process of the cryomilled powders. As the microstructural differences resulted from different milling types are compared to each other, it is evident that boride reinforcement and oxide dispersoid have a homogenous distribution throughout the surface of the S3 sample: These homogenously distributed particles having sizes between 1-2 $\mu \mathrm{m}$ are located majorly at the grain boundaries and hence inhibit the grain growth and coarsening during sintering [25]. Furthermore, unlikely the $\mathrm{S} 1$ and $\mathrm{S} 2$ samples, no pores or particle clustering are present in the SEM image of the S3 sample, indicating the positive effect of sequential milling process on the sintering ability of the composites. Thus, $10 \mathrm{~min}$ of cryomilling followed by high-energy ball milling provided the disappearance of the clustered areas of $\mathrm{TiB}_{2}$ and $\mathrm{Y}_{2} \mathrm{O}_{3}$ particles, in comparison with the SEM images of S1 and S3 samples.
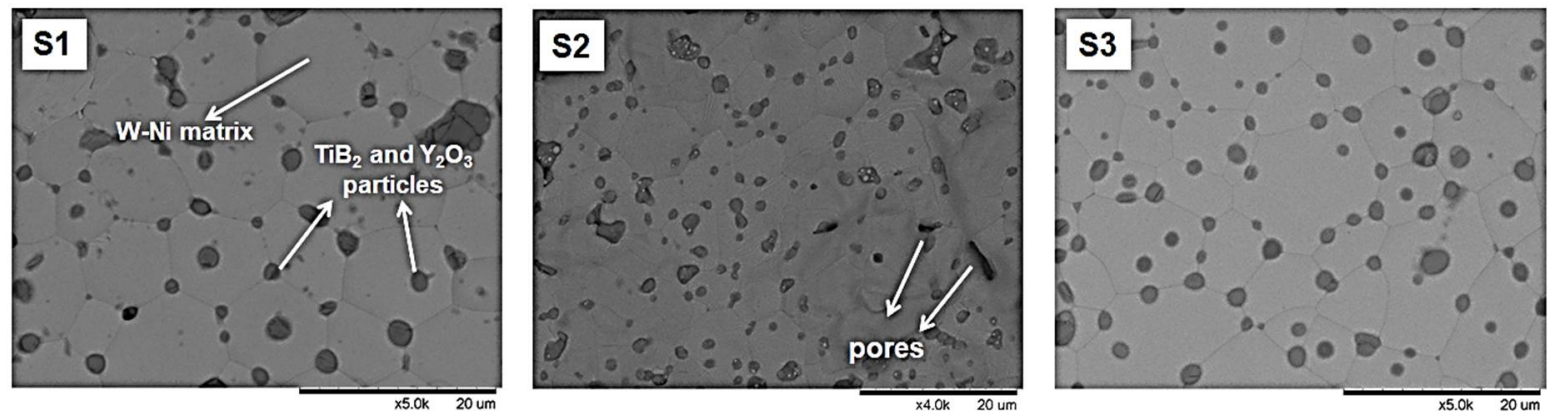

Figure 4. BSE/SEM images of the sintered samples taken from the polished surfaces.

According to the Archimedes density measurements, the relative densities of S1, S2 and S3 sintered samples were calculated as 90.79, 88.29 and $95.77 \%$, respectively. The lowest density was found in present study for the sample sintered from the cryomilled powders, whose SEM image also showed the presence of pores in the microstructure (Figure 4). On the other hand, S3 sample has the highest relative density which indicates the significant effect of sequential milling process on the densification rate, conforming well to the SEM image in Figure 4. Similar relative density $(\sim 93-97 \%)$ values were reported for the $\mathrm{Ni}$ activated sintered $\mathrm{W}$ matrix composites reinforced with boride and oxide particles $[12,15$, 19].

Figure 5 shows the average microhardness variation of the sintered samples in relation to different milling types. S2 sample sintered from the cryomilled powders has the lowest microhardness value ( $5 \mathrm{GPa}$ ), in compliance with the lowest value of relative density among the samples. As seen from Figure 5, the application of cryomilling after milling under ambient condition results in a significant increase in the microhardness value from 6.04 to $7.23 \mathrm{GPa}$ (S1 and S3). The evolution of average crystallite sizes of the powders (Table 1) and density/microhardness values (Figure 5) of the all sintered samples are in great consistency with each other, in which the decrease in average crystallite size corresponds to an increase in density/microhardness. The measured relative density and microhardness values of the sequentially milled and sintered sample are effectively high considering the powder metallurgy methods and sintering temperature $\left(1400{ }^{\circ} \mathrm{C}\right)$ used in the present study. 


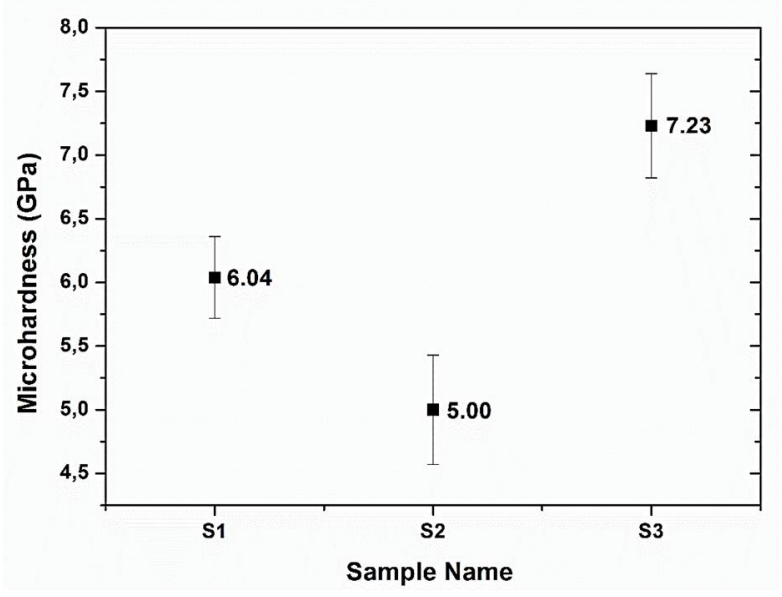

Figure 5. Average microhardness variation of the sintered samples in relation to different milling types.

Nano-indentation tests were performed individually on the $\mathrm{W}$ phase and the reinforcement/dispersoid particles in the sintered S3 sample to compare the hardness and elastic modulus values with those of pure W. Figure 6 show the load - displacement curves of the constituents in the sintered S3 sample, obtained from nano-indentation tests under maximum load of $50 \mathrm{mN}$. The curve of $\mathrm{W}$ matrix slightly shifts to smaller indentation depths for the reinforcement/dispersoid particles, indicating an increase in the indentation stiffness. The maximum penetration depths in the matrix and particles were found to be approximately 522.1 and $497.2 \mathrm{~nm}$, respectively. Thus, there is a slight difference between the amount of plastic deformation dissipated during indentation on the $\mathrm{W}$ matrix and reinforcement/dispersoid particles.

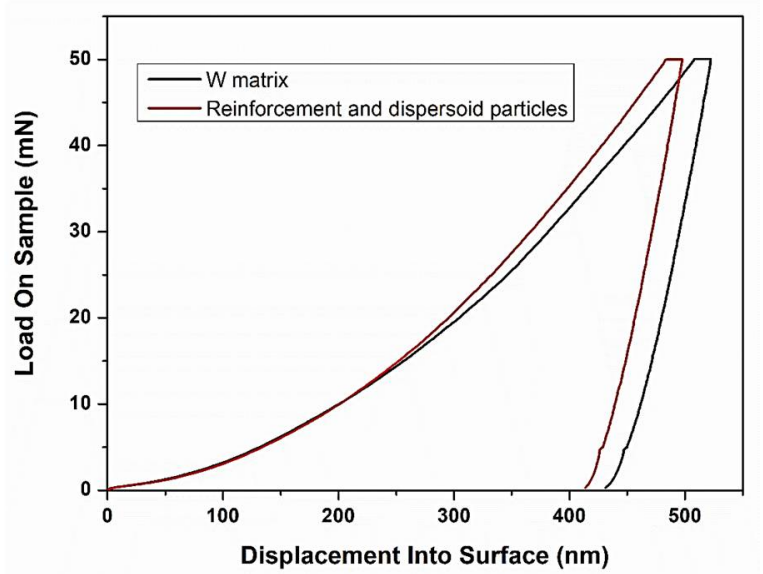

Figure 6. Load - displacement curves of the sintered S3 sample, obtained from nano-indentation tests.
The nanohardness and elastic modulus values for the constituents of S3 sample, obtained according to the Oliver-Pharr method, are listed in Table 2 [26]. The hardness $(3.4-4.6 \mathrm{GPa})$ and elastic modulus $(\sim 300 \mathrm{GPa})$ of pure tungsten is significantly improved to 8.9 and $373.7 \mathrm{GPa}$, respectively. The presence of $\mathrm{TiB}_{2}$ particles along with $\mathrm{Y}_{2} \mathrm{O}_{3}$ ones (dark contrast in the microstructure in Figure 3) resulted in a nanohardness and elastic modulus of 9.7 and $424.5 \mathrm{GPa}$, respectively. Improved nano-mechanical properties of the S3 sample having high relative density $(95.77 \%)$ can be attributed to the strengthening by the reinforcement particles distributed homogenously in the $\mathrm{W}$ matrix phase.

Table 2. Nanohardness and elastic modulus values for the constituents of S3 sample.

\begin{tabular}{ccc}
\hline & $\begin{array}{c}\mathbf{W} \\
\text { matrix }\end{array}$ & $\begin{array}{c}\mathbf{T i B}_{2} \\
\text { reinforcement/ } \\
\mathbf{Y}_{\mathbf{2}} \mathbf{O}_{3} \text { dispersoid }\end{array}$ \\
\hline $\begin{array}{c}\text { Nanohardness } \\
\text { (GPa) }\end{array}$ & 8.9 & 9.7 \\
$\begin{array}{c}\text { Elastic modulus } \\
\text { (GPa) }\end{array}$ & 373.7 & 424.5 \\
\hline
\end{tabular}

Consequently, the evaluation of present results showed that sequential milling under ambient and cryogenic conditions could be a beneficial powder preparation process to improve the microstructural and final properties (e.g. density, microhardness, elastic modulus) of the W-based composites.

\section{CONCLUSIONS}

The following conclusions can be drawn based on the results reported in the present study:

- The fabrication of tungsten matrix composites reinforced with $\mathrm{TiB}_{2}$ and $\mathrm{Y}_{2} \mathrm{O}_{3}$ particles were achieved by milling under ambient/cryogenic conditions and Ni activated sintering method.

- Only W phase was detected in all milled powders and the lowest crystallite size of 10.2 $\mathrm{nm}$ was obtained in the sequentially milled powders. After sintering, in addition to dominant $\mathrm{W}$ phase, small amounts of $\mathrm{WB}$ and 
NiW phases were detected in all sintered samples.

- Micron-scale $\mathrm{TiB}_{2}$ and $\mathrm{Y}_{2} \mathrm{O}_{3}$ particles were homogenously distributed in the microstructures of the bulk samples sintered from the sequentially milled powders. The application of $10 \mathrm{~min}$ of cryomilling after high energy ball milling for $12 \mathrm{~h}$ provided the disappearance of the clustered areas of $\mathrm{TiB}_{2}$ and $\mathrm{Y}_{2} \mathrm{O}_{3}$ particles which were located at the grain boundaries of W1Ni matrix.

- $\quad$ Sequentially milled and sintered sample had the highest relative density $(95.77 \%)$ and the highest microhardness (7.23 GPa) values.

- Nano-mechanical properties of the tungsten phase were improved due to the strengthening by the reinforcement particles distributed homogenously in the $\mathrm{W}$ matrix phase. $\mathrm{W}$ matrix phase in the sequentially milled and sintered sample yielded a nanohardness and elastic modulus of 8.9 and $373.7 \mathrm{GPa}$, respectively.

\section{Acknowledgements}

This study was supported by The Scientific and Technological Research Council of Turkey (TUBITAK) with the project number of 110M130. The authors would like to thank Koç University Surface Science and Technology Center (KUYTAM) for nano-indentation tests.

\section{REFERENCES}

[1]. Lassner E., Schubert W.D., Tungsten: Properties, Chemistry, Technology of the Element, Alloys and Chemical Compounds, Kluwer Academic, New York, 1999.

[2]. Caldwell S.G., Tungsten heavy alloys, in: Lee P.W., Lacocca R. (Eds.), Powder Metal Technologies and Applications, ASM Handbook (v. 7), ASM International, Materials Park, Ohio, (1998) 914-921.

[3]. Arshad K., Wang J., Yuan Y., Zhang Y., Zhou Z.-J. and Lu G.-H., Development of tungstenbased materials by different sintering techniques, Int. J. Refract. Met. Hard Mater., 50 (2015) 253-257.
[4]. Wei B., Wang Y., Zhao Y., Wang D., Song G., $\mathrm{Fu} \mathrm{Y}$. and Zhou Y., Effect of NbC content on microstructure and mechanical properties of W-NbC composites, Int. J. Refract. Met. Hard Mater., 70 (2018) 66-76.

[5]. Li Y., Zhang J., Luo G., Shen Q., and Zhang L., Densification and properties investigation of $\mathrm{W}-\mathrm{Cu}$ composites prepared by electrolessplating and activated sintering, Int. J. Refract. Met. Hard Mater., 71 (2018) 255-261.

[6]. German R.M. and Munir Z.A., Enhanced lowtemperature sintering of tungsten, Metall. Mater. Trans., A 7 (1976) 1873-1877.

[7]. Hayden H.W. and Brophy J.H., The activated sintering of tungsten with group VIII elements, J. Electrochem. Soc., 110 (1963) 805-810.

[8]. Song G.M., Wang Y.J. and Zhou Y., The mechanical and thermophysical properties of $\mathrm{ZrC} / \mathrm{W}$ composites at elevated temperature, Mater. Sci. Eng. A-Struct., 334 (2002) 223232.

[9]. Kim Y., Lee H.K., Kim E., Cheong D. and Hong S.H., Fabrication of high temperature oxides strengthened tungsten composites by spark plasma sintering process, Int. J. Refract. Met. Hard Mater., 27 (2009) 842-846.

[10].Chen Y., Wu Y.C., Yu F.W. and Chen J.L., Microstructure and mechanical properties of tungsten composites co-strengthened by dispersed $\mathrm{TiC}$ and $\mathrm{La}_{2} \mathrm{O}_{3}$ particles, Int. J. Refract. Met. Hard Mater., 26 (2008) 525529.

[11].Liu W., Xue L. and Yan Y., Microstructure and mechanical properties of W-Cr-TiN composite by spark plasma sintering, Fusion Engineering and Design, 125 (2017) 503-509.

[12].Ağaoğulları D., Balcı Ö., Gökçe H., Öveçoğlu M. L. and Duman I., Comparative investigations of the activated sintered $\mathrm{W}-$ 1wt.\% Ni composites reinforced with various oxide and boride particles, Int. J. Refract. Met. Hard Mater., 41 (2013) 577-584.

[13].Li B., Sun Z., Hou G., Ding F., Hu P. and Yuan $F$., The effects of alumina reinforcement and nickel activated sintering on nanosized tungsten matrix, J.Alloy. Compd., 692 (2017) 420-426. 
[14].Genç A., Çoşkun S. and Öveçoğlu M.L., Microstructural characterizations of $\mathrm{Ni}$ activated sintered $\mathrm{W}-2$ wt \% TiC composites produced via mechanical alloying, J.Alloy. Compd., 497 (2010) 80-89.

[15].Gökçe H., Balcı Ö., Ağaoğulları D., Demirkan Ö., Genç A., Öveçoğlu M.L. and Duman I., Characterization Investigations of W-Ni Matrix Composites Reinforced with $\mathrm{TiB}_{2}$ and $\mathrm{La}_{2} \mathrm{O}_{3}$, Acta Physica Polonica A, 123-2 (2013) 309-312.

[16].Balcı Ö., Demirkan Ö. U., Ağaoğulları D., Gökçe H., Genç A., Öveçoğlu M. L. and Duman I., Effects of $\mathrm{La}_{2} \mathrm{O}_{3}$ Addition on the microstructure and properties of activated sintered W-Ni Compacts, Solid State Phenomen., 194 (2012) 217-221.

[17].Munro R.G., Material properties of titanium diboride, J. Res. Natl. Inst. Stan., 105 (2000) 709-720.

[18].Battabyal M., Schäublin R., Spätig P. and Baluc N., W-2wt. $\% \mathrm{Y}_{2} \mathrm{O}_{3}$ composite: Microstructure and mechanical properties, Mat. Sci. Eng. A, 538 (2012) 53-57.

[19].Genç A., Coşkun S. and Öveçoğlu M., Fabrication and properties of mechanically alloyed and $\mathrm{Ni}$ activated sintered $\mathrm{W}$ matrix composites reinforced with $\mathrm{Y}_{2} \mathrm{O}_{3}$ and $\mathrm{TiB}_{2}$ particles, Mater. Charact., 61-7 (2010) 740748.
[20].Çoşkun S. and Öveçoğlu M.L., Effects of $\mathrm{Y}_{2} \mathrm{O}_{3}$ additions on mechanically alloyed and sintered W-4 wt $\%$ SiC composites, Int. J. Refract. Met. Hard Mater., 29 (2011) 651655.

[21].Gupta V.K., Yoon D.H., Meyer H.M. and Luo J., Thin intergranular films and solidstate activated sintering in nickel-doped tungsten, Acta Mater., 55 (2007) 3131-3142.

[22].Ağaoğulları D., Balcı Ö. and Öveçoğlu M. L., Effect of milling type on the microstructural and mechanical properties of $\mathrm{W}-\mathrm{Ni}-\mathrm{ZrC}-\mathrm{Y}_{2} \mathrm{O}_{3}$ composites, Ceram. Int., 43-9 (2017) 71067114.

[23].Back S.H., Lee G.H. and Kang S., Effect of cryomilling on particle size and microstrain in a WC-Co alloy, Mater. Trans., 46-1 (2005) 105-110.

[24].Veleva L., Oksiuta Z., Vogt U. and Baluc N. Sintering and characterization of $\mathrm{W}-\mathrm{Y}$ and $\mathrm{W}-\mathrm{Y}_{2} \mathrm{O}_{3}$ materials. Fusion Eng. Des., 84 (2009) 1920-1924.

[25].Suryanarayana C., Mechanical alloying and milling, Prog. Mater. Sci., 46 (2001) 1-184.

[26].Oliver W.C. and Pharr G.M., An improved technique for determining hardness and elastic modulus using load and displacement sensing indentation experiments, Journal of Materials Research 7-6 (1992) 1564-1583. 